\title{
THE INFLUENCE OF CHANGING OF TREATMENT CONDITION ON SURFACE ROUGHNESS PARAMETER DURING TURNING PROCESS BY WIPER INSERT
}

\author{
Wojciech Labuda \\ Gdynia Maritime University, Faculty of Marine Engineering \\ Morska Street 83, 81-225 Gdynia, Poland \\ tel.: +48585586549,fax: +48585586399 \\ e-mail:w.labuda@wm.umg.edu.pl
}

\begin{abstract}
One of the greatest problems of modern production techniques is the achievement of an appropriate quality at minimal costs and accompanied by the production efficiency increase. Therefore, while designing the production process. The technology used should have a considerable influence on the durability and reliability of machine parts to be produced. During finish treatment, the final dimensions as well as functional properties are imparted to a given element by application of proper treatment type. The engineer has a range of production techniques to choose for the proper surface layer formation. It is crucial to find a suitable solution which will meet the requirements as well as the work conditions of a given machine part. The article presents the results of influence of change of cutting parameters on surface roughness parameter during turning process of stainless steel. A shaft made of 304L stainless steel was used for the research. The chemical composition of steel was measured by Solaris-ccd plus optical spectrometer. The cutting process was carried out on a universal CDS 6250 BX-1000 centre lathes. Measurement of surface roughness was carried out by T8000 profilometer. The turning process was conducted by a cutting tool with Wiper insert. During the turning, the following machining parameters were used: cutting speed $V_{c}[\mathrm{~m} / \mathrm{min}]$, feed $f$ [mm/rev], cutting depth ap [mm] and additionally changed nose radius $r$ [mm], and tool cutting edge angle $\varkappa_{r}\left[{ }^{\circ}\right]$. The results of measurements of Ra parameter underwent statistic analysis. The calculations were conducted by Statistica software.
\end{abstract}

Keywords: finish turning process, surface roughness parameter, cutting parameters, stainless steel

\section{Introduction}

Vessels and warships are equipped with main propulsion engines, generating sets and auxiliary machinery, which are used in the engine room as well as on deck. Seawater pumps belong to a group of centrifugal angular momentum pumps. Their wide application on board vessels is related to their numerous advantages, which comprise simple construction, good performance characteristic, easy adjustment, quiet work, and the possibility of applying direct electric motor drive. Centrifugal angular momentum pumps are utilized in the cooling system of high and medium speed engines, for supplying boilers, in bilge systems, ballast systems and in firefighting installations. During their service, the wear of pump body, rotor, sealing, and shaft takes place. The research work made an effort to improve the shafts service durability, and it was based on carrying out tests for contact fatigue, friction wear, and electrochemical corrosion.

Due to hard service conditions, marine pumps working in seawater environment are made of corrosion resistant materials. In spite of the fact that pump shafts are made of an expensive material, it is not possible to avoid service damage. This damage includes cracking, plastic deformation, excessive wear of pins in places of mounting rotor discs and sealing chokes, corrosive wear, friction wear, erosive wear and spline ways knock outs. During service experience, the most common problem that is observed is excessive wear of pins causing their diameter decrease as well as exceeding the permissible shape deviations in place of chokes mounting. Many scientific centres, including Gdynia Maritime University, deal with issues related to the turning surface of the difficult-to-machine [1, 2, 4-13]. The research aims to determine a set of input 
factors, fixed and distorting for the finish lathing of pins shafts made of stainless steel, had an impact on geometrical structure of the surface, as well as on the values of forces and cutting temperature. Machining stainless steels, especially austenitic steel causes many difficulties. On the machinability of austenitic steel has a negative impact high propensity to the deformation strengthening, low thermal conductivity, and good ductility. Alloying element improves the machinability of stainless steels is sulphur. Sulphur in combination with manganese forms MnS manganese sulphide, which positive influence on machinability is confirmed by the type of chips (short and brittle), smoother surfaces of workpieces and less tool wear.

For the basic method of the surface layer, forming of shaft pins is known lathing. Conventional machining accuracy is usually considered as a function of the characteristics of all the components of machine tool, fixture, object, and tool. There are accuracy performance and the accuracy of static and dynamic determining and cutting parameters, which are associated with strength, temperature, and wear of the cutting edge. Therefore, stock removal of high efficiency should be performed in a controlled manner, which ensures the correct shape and size of the chip.

The article is a continuation of the research on influence of changing the treatment condition during turning process of stainless steel. The publish presents the results of influence of change of cutting parameters during turning of shafts by Wiper insert on Ra parameter.

\section{The research methodology}

During research of surface roughness parameters, the shafts made of stainless steel were used (Fig. 1b). The process of turning was carried out on a universal CDS 6250 BX-1000 lathe centre (Fig. 1a). The lathing process was conducted by a cutting tool with CCET09T302 WF, CCMT 09T304 WF, and CCMT 09T308 WF inserts. Changes in the angle $x_{r}$ in the range of \pm 3 carried out by twisting the compound rest. In order to analyse of influence change of treatment conditions for Wiper insert on the obtained surface roughness parameter, parameter Ra was used. The inserts of cutting tools were mounted in a dynamometer, which was additionally used to record forces during the cutting process.
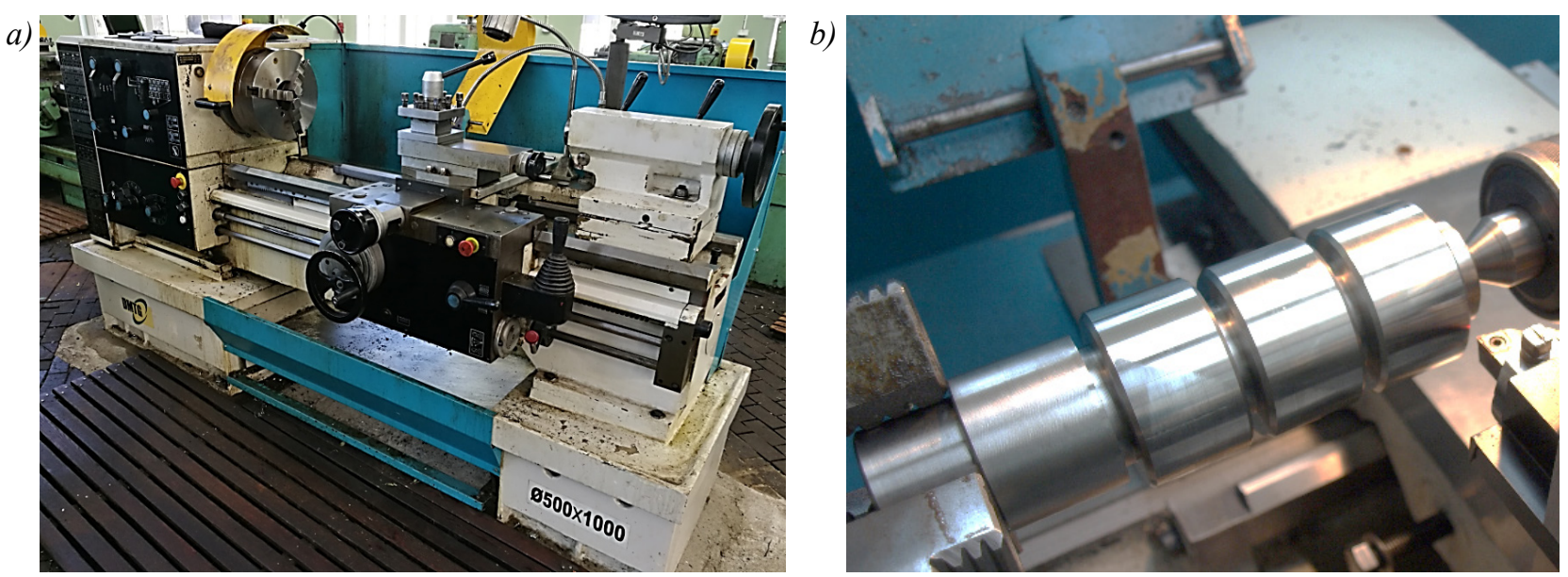

Fig. 1. a) Lathe type: CDS $6250 \mathrm{BX}-1000$, b) the sample used for turning process

During the turning process, the following machining parameters were used: cutting speed (Vc), feed (f) and depth of cut (ap). The values of cutting parameters are presented in Tab. 1.

DKM 2010 is a 5-components tool dynamometer for use on conventional or CNC lathe machines. It measures force on the cutting tool up to $2000 \mathrm{~N}$ with a resolution of $0.1 \%$ and as option also temperatures on the tool tip between 300 and $800^{\circ} \mathrm{C}$. DKM 2010 is equipped with adjustable inserts - holder to change entering angle $\varkappa_{\mathrm{r}}$ into $45,60,70,90^{\circ}$. The equipment of DKM 2010 is presented in Fig. 2. 
Tab. 1. The cutting parameters used in turning process

\begin{tabular}{|c|c|c|c|}
\hline \multirow{2}{*}{ Type of inserts } & \multicolumn{3}{|c|}{ Cutting parameters } \\
\cline { 2 - 4 } & $\mathrm{Vc}[\mathrm{m} / \mathrm{min}]$ & $\mathrm{f}[\mathrm{mm} / \mathrm{rev}]$ & $\mathrm{ap}[\mathrm{mm}]$ \\
\hline CCMT 09T302 WF & $160 ; 230$ & $0.099 ; 0.106$ & $0.3 ; 0.5$ \\
\hline CCMT 09T304 WF & $160 ; 230$ & $0.106 ; 0.198$ & $0.5 ; 1.0$ \\
\hline CCMT 09T308 WF & $113 ; 160$ & $0.106 ; 0.248$ & $0.5 ; 1.0$ \\
\hline
\end{tabular}

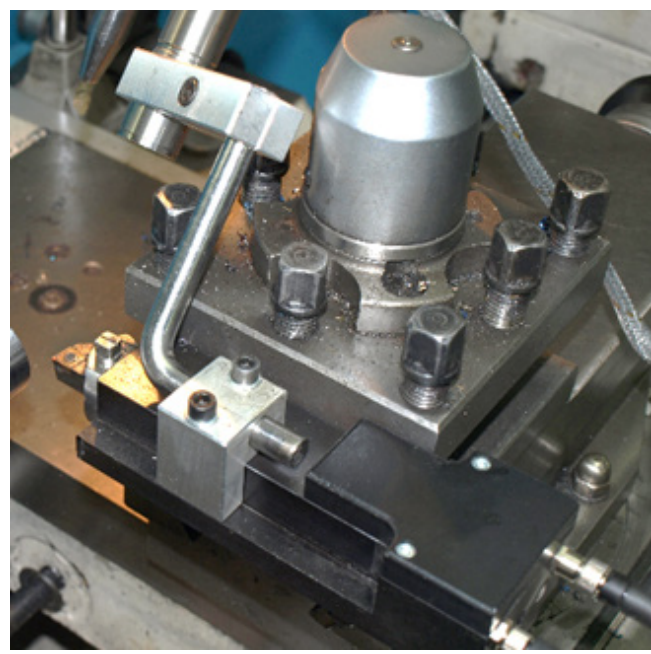

Fig. 2. DKM 2010 turning dynamometer

Analysis of the chemical composition of the sample material was carried out on a Solaris-ccd plus spectrometer (Fig. 3a). It is an optical emission spectrometer with spark excitation by GNR. It performs the analysis of solid samples and metal alloys of different matrices. Percentage contents of selected elements in steel were presented for sample after four-spark test (Fig. 3b).

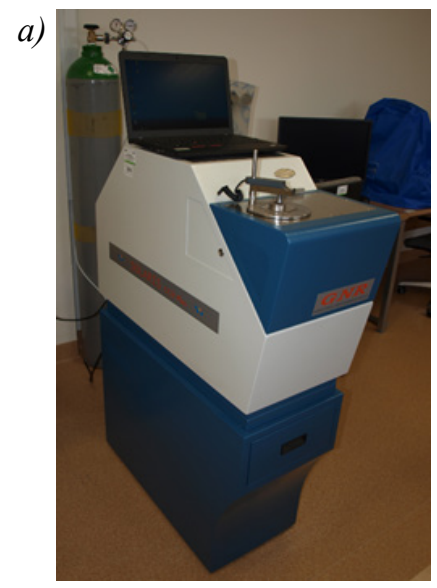

b)

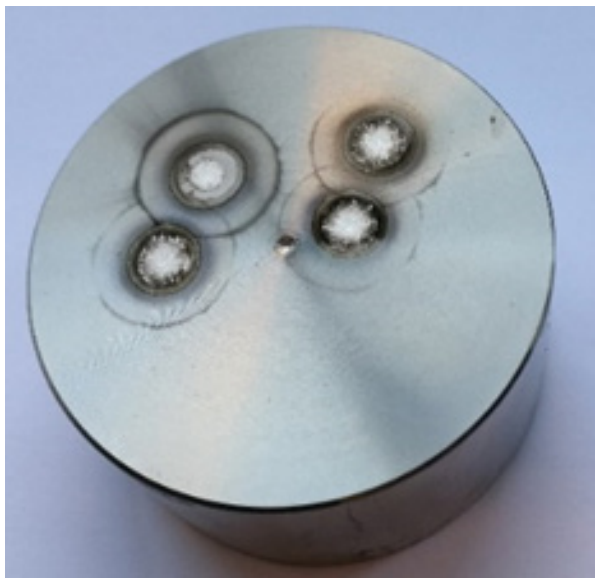

Fig. 3. a) Solaris-ccd plus optical spectrometer, b) the sample used for the chemical composition testing

The surface roughness was measured by T8000 profilometer. For the test used measuring tip with a $2-\mu \mathrm{m}$ radius. The analysis covered the parameter of surface roughness $\mathrm{Ra}$ (arithmetic mean deviation of the assessed profile).

The results of influence of changing treatment condition underwent statistic analysis of multiple regression in order to determine their influence on surface roughness examined. The calculations were conducted by Statistica software. Due to different independent variables, the influence of particular parameters was analysed on the basis of standardized regression factors where: 
- BETA - standardized multiple regression coefficient,

- B - estimator of the multiple regression coefficient,

- $p$ - calculated significance level; if its value is less than the accepted significance level a, the zero hypothesis, stating that the independent variable does not have a significant effect on the value of a dependent variable, is to be rejected; when $a<p$, then at the given significance level a, there are no grounds for rejecting the zero hypothesis.

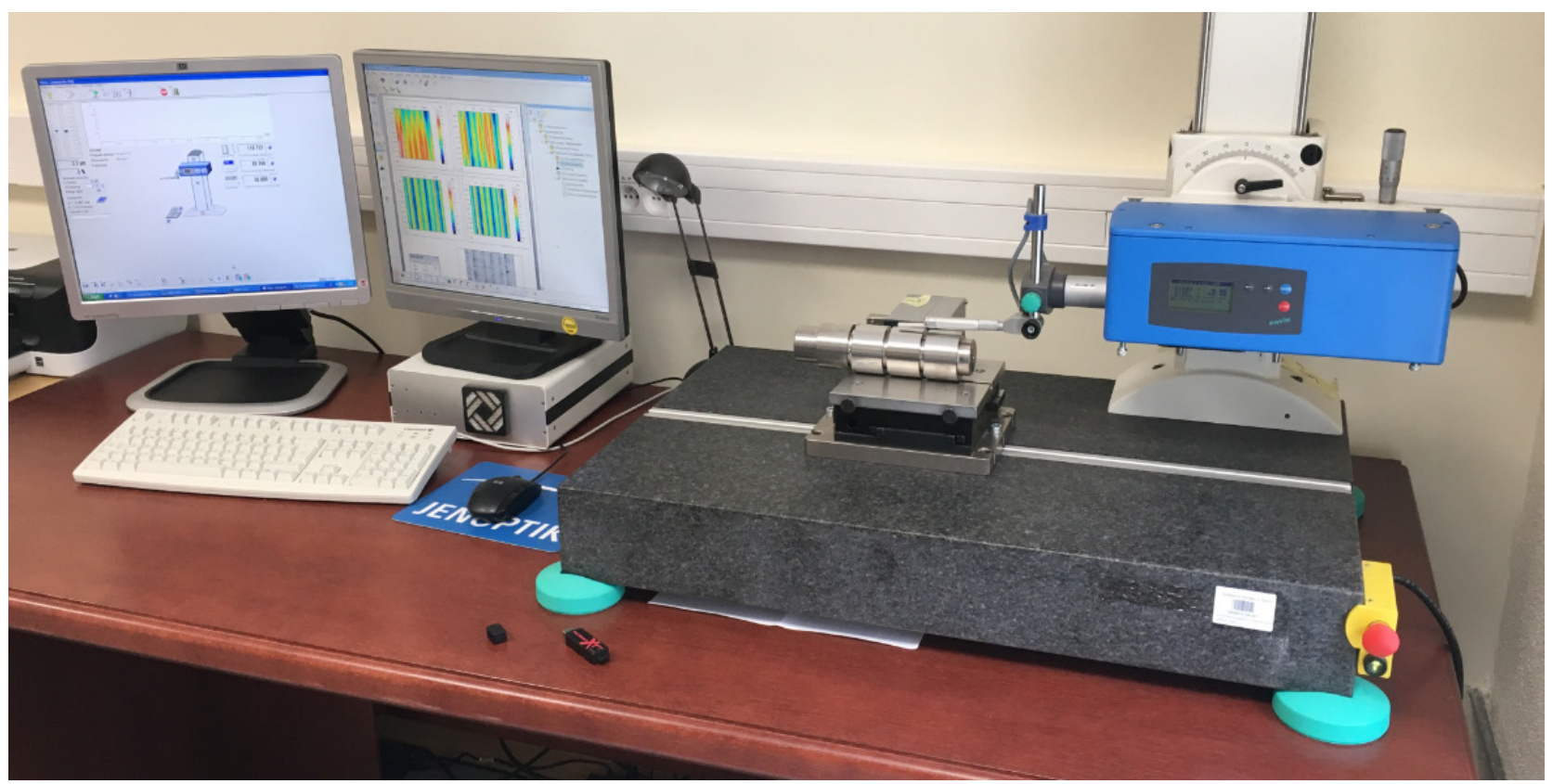

Fig. 4. T8000 profilometer

\section{The research results}

The results of the chemical composition of 304L steel is presented in Tab. 2. Austenitic steels containing $8 \% \mathrm{Ni}$ have the preferred combination of machinability, mechanical properties, and corrosion resistance. They are the most important group of stainless steels. Machining of stainless steels is classified as a group of materials difficult to machining process [3].

Tab. 2. The results of the chemical composition of tested steel [\%]

\begin{tabular}{|c|c|c|c|c|c|c|c|c|c|}
\hline & $\mathrm{C}$ & $\mathrm{Si}$ & $\mathrm{Mn}$ & $\mathrm{P}$ & $\mathrm{S}$ & $\mathrm{Cr}$ & $\mathrm{Mo}$ & $\mathrm{Ni}$ & $\mathrm{Nb}$ \\
\hline mean & 0.037 & 0.457 & 1.638 & 0.028 & 0.030 & 18.261 & 0.473 & 7.760 & 0.008 \\
\hline $\max$ & 0.057 & 0.478 & 1.659 & 0.030 & 0.033 & 18.332 & 0.482 & 7.847 & 0.010 \\
\hline $\min$ & 0.025 & 0.440 & 1.612 & 0.026 & 0.028 & 18.164 & 0.465 & 7.628 & 0.006 \\
\hline & $\mathrm{Al}$ & $\mathrm{Cu}$ & $\mathrm{Co}$ & $\mathrm{B}$ & $\mathrm{Ti}$ & $\mathrm{V}$ & $\mathrm{W}$ & \multicolumn{2}{|c|}{$\mathrm{Fe}$} \\
\hline mean & 0.003 & 0.483 & 0.125 & 0.002 & 0.026 & 0.057 & 0.021 & 70.594 \\
\hline max & 0.004 & 0.490 & 0.127 & 0.002 & 0.027 & 0.058 & 0.021 & 70.731 \\
\hline $\min$ & 0.002 & 0.471 & 0.124 & 0.001 & 0.023 & 0.057 & 0.020 & 70.482 \\
\hline
\end{tabular}

Table 3 shows the results of influence of changing treatment condition on the surface roughness parameter. The value of parameter $\mathrm{Ra}$ is the mean value of 3 measurements.

Final values of standard regression coefficients (BETA), coefficients (B), and significance levels ( $\mathrm{p}$ levels) of the multiple regression analysis were presented in Tab. 4. The remaining coefficients take constant values and are respectively: correlation coefficient $\mathrm{R}=0.88$, determination coefficient $\mathrm{R} 2=0.73, \mathrm{~F}(5,25)=17.513, \mathrm{p}<.00000$ estimation error: 0.34 . 
Tab. 3. The results of influence treatment condition on Ra parameter [ $\mu \mathrm{m}]$

\begin{tabular}{|c|c|c|c|c|c|}
\hline \multicolumn{3}{|c|}{ Cutting parameters } & \multirow{2}{*}{$\mathrm{r}[\mathrm{mm}]$} & \multirow{2}{*}{$x_{\mathrm{r}}\left[^{\circ}\right]$} & \multirow{2}{*}{$\operatorname{Ra}[\mu \mathrm{m}]$} \\
\hline $\mathrm{Vc}[\mathrm{m} / \mathrm{min}]$ & ap [mm] & $\mathrm{f}[\mathrm{mm} / \mathrm{rev}]$ & & & \\
\hline 160 & 0.5 & 0.106 & 0.2 & 90 & 0.81 \\
\hline 160 & 0.5 & 0.106 & 0.4 & 90 & 0.65 \\
\hline 160 & 0.5 & 0.106 & 0.8 & 90 & 0.72 \\
\hline 230 & 0.3 & 0.099 & 0.2 & 87 & 1.16 \\
\hline 230 & 0.3 & 0.099 & 0.2 & 88 & 0.80 \\
\hline 230 & 0.3 & 0.099 & 0.2 & 89 & 0.85 \\
\hline 230 & 0.3 & 0.099 & 0.2 & 90 & 0.69 \\
\hline 230 & 0.3 & 0.099 & 0.2 & 91 & 0.72 \\
\hline 230 & 0.3 & 0.099 & 0.2 & 90 & 0.71 \\
\hline 230 & 0.3 & 0.099 & 0.2 & 93 & 1.51 \\
\hline 230 & 1 & 0.198 & 0.4 & 87 & 2.72 \\
\hline 230 & 1 & 0.198 & 0.4 & 88 & 2.50 \\
\hline 230 & 1 & 0.198 & 0.4 & 89 & 2.20 \\
\hline 230 & 1 & 0.198 & 0.4 & 90 & 1.88 \\
\hline 230 & 1 & 0.198 & 0.4 & 91 & 1.55 \\
\hline 230 & 1 & 0.198 & 0.4 & 92 & 1.36 \\
\hline 230 & 1 & 0.198 & 0.4 & 93 & 0.98 \\
\hline 160 & 1 & 0.248 & 0.8 & 87 & 2.35 \\
\hline 160 & 1 & 0.248 & 0.8 & 88 & 2.14 \\
\hline 160 & 1 & 0.248 & 0.8 & 89 & 1.93 \\
\hline 160 & 1 & 0.248 & 0.8 & 90 & 1.75 \\
\hline 160 & 1 & 0.248 & 0.8 & 91 & 2.07 \\
\hline 160 & 1 & 0.248 & 0.8 & 92 & 2.22 \\
\hline 160 & 1 & 0.248 & 0.8 & 93 & 1.92 \\
\hline 113 & 1 & 0.248 & 0.8 & 87 & 2.59 \\
\hline 113 & 1 & 0.248 & 0.8 & 88 & 2.55 \\
\hline 113 & 1 & 0.248 & 0.8 & 89 & 2.42 \\
\hline 113 & 1 & 0.248 & 0.8 & 90 & 1.79 \\
\hline 113 & 1 & 0.248 & 0.8 & 91 & 1.47 \\
\hline 113 & 1 & 0.248 & 0.8 & 92 & 1.47 \\
\hline 113 & 1 & 0.248 & 0.8 & 93 & 1.48 \\
\hline
\end{tabular}

When examining the values of standardized multiple regression coefficients obtained for independent variables it is possible to state that feed $(\mathrm{BETA}=0.89)$ has the greatest impact on $\mathrm{Ra}$ parameter. The lower the feed value used for turning process, the lower the value of mean arithmetic deviation of $\mathrm{Ra}$ roughness profile. The second significant variable affecting the quality of the surface achieved is the tool cutting edge angle $(\mathrm{BETA}=-0.38)$. The increase of $\boldsymbol{x}_{\mathrm{r}}$ results in the decrease of Ra parameter value. Simultaneously, analysis indicated, that Vc, ap and r variables are statistically irrelevant for the parameter defining the stereometric structure of shaft pins.

Coefficient BETA for this the variables are characterized by a high value of the calculated significance level (for $\mathrm{Vc}: \mathrm{p}=0.33$; ap: $\mathrm{p}=0.78$; $\mathrm{r}: \mathrm{p}=0.76$ ). This is indicative of a lack of statistical significance of the effect of the considered parameters on the geometric structure of shaft pins surfaces. This is confirmed by multiple regression analysis, in which the independent variable of nose radius (Tab. 5) and next parameter of cutting speed (table 6) were not taken into account. 
Tab. 4. The results of Ra parameter statistic analysis for variables presented in Tab. 3

\begin{tabular}{|l|c|c|c|}
\hline & BETA & B & p level \\
\hline Free term & & 11.448 & 0.00 \\
\hline $\mathrm{Vc}[\mathrm{m} / \mathrm{min}]$ & 0.19 & 0.003 & 0.33 \\
\hline $\mathrm{ap}[\mathrm{mm}]$ & 0.09 & 0.197 & 0.78 \\
\hline $\mathrm{f}[\mathrm{mm} / \mathrm{rev}]$ & 0.89 & 9.154 & 0.04 \\
\hline$\left.\kappa{ }^{\circ}\right]$ & -0.38 & -0.134 & 0.00 \\
\hline $\mathrm{r}[\mathrm{mm}]$ & -0.08 & -0.207 & 0.76 \\
\hline
\end{tabular}

Coefficients BETA, B, and $\mathrm{p}$ level for advance nose radius and cutting force reached the same values for both analyses. In another statistical analysis with omission of variable $\mathrm{Vn}$, the regression equation matched the obtained real results on the same level, of which the values of the coefficient of correlation and of coefficient determination $\mathrm{R} 2$ are indicative.

The values of standard regression coefficients (BETA), coefficients (B), and significance levels ( $\mathrm{p}$ levels) of the multiple regression analysis that was carried out without taking depth of cut into account were presented in Tab. 5. The remaining coefficients take constant values and are respectively: correlation coefficient $\mathrm{R}=0.88$, determination coefficient $\mathrm{R} 2=0.74, \mathrm{~F}(4,26)=$ $=22.68, \mathrm{p}<.00000$ estimation error: 0.33 .

Tab. 5. The results of Ra parameter statistic analysis for variables presented in Tab. 3 without taking into account the depth of cut

\begin{tabular}{|l|c|c|c|}
\hline & BETA & \multicolumn{1}{|c|}{ B } & p level \\
\hline Free term & & 11.342 & 0.00 \\
\hline $\mathrm{Vc}[\mathrm{m} / \mathrm{min}]$ & 0.20 & 0.003 & 0.26 \\
\hline $\mathrm{f}[\mathrm{mm} / \mathrm{rev}]$ & 0.99 & 10.193 & 0.00 \\
\hline$\left.\kappa{ }^{\circ}\right]$ & -0.38 & -0.134 & 0.00 \\
\hline $\mathrm{r}[\mathrm{mm}]$ & -0.09 & -0.223 & 0.74 \\
\hline
\end{tabular}

The values of standard regression coefficients (BETA), coefficients (B), and significance levels ( $p$ levels) of the multiple regression analysis that was carried out without taking depth of cut and nose radius into account were presented in Tab. 6 . The remaining coefficients take constant values and are respectively: correlation coefficient $\mathrm{R}=0.88$, determination coefficient $\mathrm{R} 2=0.75$, $\mathrm{F}(4,27)=31.23, \mathrm{p}<.00000$ estimation error: 0.33 .

Tab. 6. The results of Ra parameter statistic analysis for variables presented in Tab. 3 without taking into account the depth of cut and nose radius

\begin{tabular}{|l|c|c|c|}
\hline & BETA & B & p level \\
\hline Free term & & 11.207 & 0.00 \\
\hline $\mathrm{Vc}[\mathrm{m} / \mathrm{min}]$ & 0.25 & 0.003 & 0.04 \\
\hline $\mathrm{f}[\mathrm{mm} / \mathrm{rev}]$ & 0.94 & 10.193 & 0.00 \\
\hline$\kappa\left[^{\circ}\right]$ & -0.38 & -0.134 & 0.00 \\
\hline
\end{tabular}

Performing a statistical analysis without depth of cut and nose radius showed that the biggest influence on the surface roughness parameter Ra has feed (BETA $=0.94)$, tool cutting edge angle $(\mathrm{BETA}=-0.38)$ and cutting speed $(\mathrm{BETA}=0.25)$.

The regression equation for theoretical $\mathrm{Ra}_{\mathrm{t}}$ parameter was as follows:

$$
\mathrm{Ra}_{\mathrm{t}}=0.003 \cdot \mathrm{Vc}+10.193 \cdot \mathrm{f}-0.38 \cdot \kappa \pm 0.33[\mu \mathrm{m}] .
$$




\section{Conclusions}

Modern processes of machining, especially difficult-to-work materials, which are widely used in industry, should ensure the best possible quality of products high efficiency economy reliability and eco-efficiency. Due to the high requirements of elements made of difficult materials and the need for effective simultaneous machining of these materials are carried out extensive research on the improvement of machining processes.

Analysis of the results showed significant differences in the values obtained for surface roughness parameter during changing of cutting parameters, nose radius and tool cutting edge angle.

The turning process using the Wiper insert on the conventional lathes requires the correct setting of the turning tool relative to the material. The operator can make a mistake in setting the cutting edge in such a way, that the edge will not smooth the surface irregularities of the surface, and the Wiper insert will be perform the cutting process as a standard plate. Therefore, it is important to choose correct cutting parameters and correct positioning of the cutting tool, especially on the conventional lathe.

In the next research, a multiple regression analysis will be performed to determine the equations for cutting forces for variable treatment conditions. In addition, research is conducted to determine the effect of changing treatment conditions on the geometric structure of the surface.

\section{References}

[1] Agustina, B., Bernal, C., Camacho, A. M., Rubio, E. M., Experimental Analysis of the Cutting Forces Obtained in Dry Turning Processes of UNS A97075 Aluminium Alloys, The Manufacturing Engineering Society International Conference, MESIC, Procedia Engineering, Vol. 63. pp. 694-699, 2013.

[2] Bensouilah, H., Aouici, H., Meddour, I., Yallese, M. A., Mabrouki, T., Girardin, F., Performance of coated and uncoated mixed ceramic tools in hard turning process, Measurement, Elsevier, 2015.

[3] Callister, W. D. Jr., Materials Science and Engineering an Introduction, John Wiley \& Sons Inc., USA 2007.

[4] Dudzik, K., The influence of welding parameters on the quality of joints made by FSW of AW5083 aluminium alloy, In METAL 2016: 25th Anniversary International Conference on Metallurgy and Materials, pp. 694-699, Tanger, Ostrava 2016.

[5] Dyl, T., Starosta, R., Określenie wpływu geometrii i rodzaju materiału płytek skrawajacych na topografię toczonych powtok kompozytowych, Inżynieria Materiałowa, $\mathrm{Nr} 6$. pp. 701-704, 2012.

[6] Dyl, T., Starosta, R., Wpływ geometrii i gatunku płytek skrawajacych na strukturę geometryczna toczonych powłok stopowych, Inżynieria Materiałowa, Nr 4, pp. 395-398. 2011.

[7] Labuda, W., Khudoley, A., The influence of burnishing process on surface roughness of stainless steel researched by optical profiler, In METAL 2016: 25th Anniversary International Conference on Metallurgy and Materials, pp. 765-770, Tanger, Ostrava 2016.

[8] Labuda, W., The influence of changing the side angle of the cutting tool by Wiper technology on the value of material ratio parameters of steel applied to marine pump shaft pins, Journal of KONES Powertrains and Transport, Vol. 22, No. 2, pp. 139-147, 2015.

[9] Labuda, W., The influence of cutting inserts geometric on surface roughness of steel applied to sea water pump shafts, Journal of KONES Powertrains and Transport, Vol. 22, No. 3, pp. 133-140, 2015.

[10] Labuda, W., The analysis of cutting tool geometric on cutting forces and surface roughness of steel applied to marine pumps shaft pins, Journal of KONES Powertrains and Transport, Vol. 21, No. 1, pp. 147-152, 2014. 
[11] Magri, A., Diniz, A. E., Suyama, D. I., Evaluating the use of high-pressure coolant in turning process of Inconel 625 nickel-based alloy, Proceedings of the Institution of Mechanical Engineers part B-Journal of Engineering Manufacture, Vol. 232, pp. 1182-1192, 2018.

[12] Sadilek, M., Dubsky, J., Sadilkova, Z., Poruba, Z., Cutting forces during turning with variable depth of cut, Perspectives in Science, Elsevier, 2015.

[13] Starosta, R., Dyl, T., Obróbka wykańczajaca natryskiwanych płomieniowo powłok Ni-Al. ocena zużcia borazonowych ptytek skrawajacych, Tribologia. Teoria i Praktyka, Nr 4. pp. 245-252. 2011.

Manuscript received 12 December 2018; approved for printing 14 March 2019 